\title{
Exploring transitions in notions of identity as perceived by beginning post-compulsory teachers
}

\author{
Dr. Victoria Wright, Theresa Loughlin, Dr. Val Hall
}

Faculty of Education, Health and Wellbeing, University of Wolverhampton, Walsall campus, $U K$

Dr. Victoria Wright

FEHW/IoE

University of Wolverhampton

Walsall campus

Gorway Road

Walsall

WS1 1BD

\section{V.Wright@wlv.ac.uk}

Both Victoria Wright and Theresa Loughlin are Senior Lecturers in Post Compulsory Education who work primarily on the full time one year PGCE in Post Compulsory Education and on the part time MA in Professional Practice and Lifelong Education. Val Hall is a Principal Lecturer, Head of Lifelong Learning Partnerships, and her teaching work likewise includes the PGCE PCE and the MA Professional Practice and Lifelong Education. All three have substantial experience working in Further Education institutions and Higher Education and on a range of teacher education and professional development provision. 


\section{Exploring transitions in notions of identity as perceived by beginning post-compulsory teachers}

This paper reports on Phase Two of a small scale qualitative research project. Phase One (2015-2016) focused on pre-service student teachers' perceptions of observation and feedback in relation to their developing identity as teachers. In Phase Two, two previous participants reflected on the research findings as qualified and beginning teachers. New participants were invited to contribute their perspectives of the transition they had made from the PGCE PCE (Postgraduate Certificate in Post Compulsory Education) one year full time course to their first year of teaching.

Phase Two considers constructs of teacher identity and theoretical models of communities of practice and ecological learning systems. Participants reviewed transitions from PGCE PCE in to their first year of teaching in relation to a continuum of practice that saw them taking increased levels of ownership of their development. They described the extent to which and the ways in which they identified themselves with the teacher role and as members of a community at work. Applications of the community of practice model were discussed and occasionally compared unfavourably to the community of practice context of the PGCE PCE course. Community of practice concepts such as 'membership' and 'validation' are re-explored in this paper.

Keywords: community of practice; ecological learning systems; teacher identity; teacher agency; mentoring

\section{Introduction}

The paper reports on a small scale qualitative research project that originally began: (2015-2016), with a specific focus on pre-service student teachers' perceptions of lesson observation and feedback in relation to their developing identity as teachers. The research was undertaken at a university by tutors working on the post compulsory teacher education programme (PGCE PCE) and is situated in the context of lifelong teacher education. It is written in the spirit of 'Reimagining Further Education': turning 
a lens directly on teachers' own narratives in order to start a discussion as to how teachers' sense of identity and agency might be better nurtured and sustained.

In this study, all participants had attended the full time one year Postgraduate Certificate in Post Compulsory Education but their particular route differed. We have three routes: generic (mixed subjects), skills (typically English/ Literacy/ ESOL but might also include Maths) and Graduate Teaching Assistant (for those on a two year contract with the university).

A further extension of this project is envisaged (2017-2018) which will open up opportunities for teachers in the lifelong learning sector (not all directly from the University's PGCE PCE programme) to explore (and write collaboratively about) the transitions they have made in their career, thinking about perceptions of agency, identity and the ways in which those professional trajectories are formed and reformed.

\section{Development of research project, from 2015-2016 to 2016-2017}

In 2015-2016, eight PGCE PCE student teachers participated to varying degrees (five to all of the data collection opportunities). The data collection comprised: i) individually written pen portraits, ii) focus group discussion on observation and feedback, iii) analysis of student teacher contributions in a developmental peer colleague observation feedback dialogue, and iv) semi structured interview through which to review and reflect.

Thematic strands were identified as: 'teacher-student relationship', 'teacher identity', 'open to developing', 'observation as performance' (see Wright, Loughlin and Hall's 2017 recent TEAN paper publication). As researchers (two of whom were personal tutors supporting and observing teaching practice on the PGCE PCE course), it was very interesting to note at what points and in what ways student teachers' perceptions might shift. This oscillation was noted variously along a continuum 
between traditional concepts of a community of practice, such as a master-apprentice model with students positioning themselves as learning from a more experienced other, to a more active engagement with their own professional development more aligned to ecological learning systems. This sense of greater agency initiated through ecological learning systems results from greater fluidity and the potential for multiple levels of interaction and bi-directionality of influence; an absence of hierarchy and sense of 'place'; and an absence of having to 'know' and 'be known by' that community in order to be accepted.

Participants were provided with a summary of both community of practice and ecological learning concepts as well as the thematic strands and this became a focus for the semi-structured interview. In that interview, they were asked to reflect on the researchers' analyses in the following ways:

(1) To what extent do you feel this (this information already gleaned) represents you?

(2) How does this differ from your own perspective?

(3) How do you see yourself developing in the light of those representations?

In 2016-2017, two of the original participants and five new participants contributed. All seven participants successfully completed the PGCE PCE in 20152016. All were in employment or second year of a two year contract with the university. They were provided with an overview of the research to date as a way of situating the project. They were invited to attend an interview with a researcher and to report back on the summary analysis generated from that interview. Further details are provided in the methodology and ethics section later in this paper.

\section{Policy context}


The policy context for this paper is the further education (FE) or post-compulsory education (PCE) sector which has probably undergone the most profound changes of all the education sectors in England. More recently in July 2015 the Department of Business, Innovation and Skills (DBIS) established the 'Post-16 area reviews' in the form of geographical regional appraisals of the sector's provision for education and training, the DBIS making clear their ambitions for 'a move towards fewer, often larger, more resilient and effective providers' (DBIS and DfE 2015, 3).

The key drivers for policy change have been well established with the dominant discourse of a skills driven agenda underpinned by the needs for employability of learners going through the system, a responsiveness to local employers' needs and to support the wider national economic priorities, including the advent of Brexit (DBIS and DfE 2015; Gleeson et al. 2014; Smith and O'Leary 2013; Leitch 2006). The Post16 area review outcomes have been as predicted (DBIS and DfE 2015). The reported recommendations stated where colleges in localised areas needed to merge for improved sustainability and economies of scale. Whatever the outcomes, the emphasis of the area reviews is that the changes; such as joint managed services, work in the best interests of the learners. For newly qualified teachers entering the sector (the research context of this paper), this has meant transformations in professional practice. With performance measurability being high on the agenda, those governing, leading and managing colleges will inevitably need to impose further demands for robust management and even performance objectives (Esmond and Wood 2017; Ball 2010) on those at the grass roots of teaching and learning.

The Carter Review of Initial Teacher Training (ITT) (2015) highlights the neoliberal policy complexities of teacher education which also has resonance with the research discussed in this paper and highlights the "competing conceptions of teacher 
quality and professional learning" (Mutton et al. 2016, 15). The Department for Education (DfE) has continued to deregulate ITT in England for a number of years, moving away from the dominance of higher education institutions (HEIs) and moving towards a greater role for schools and head teachers in the formation of newly qualified teachers. These ongoing initiatives were highlighted in the Government White Paper (DfE 2010), 'The Importance of Teaching' and more recently in March (DfE 2016), in 'Educational Excellence Everywhere' where their view is that teaching can only be learned in the context of the classroom, learnt as an apprentice. Additionally, in the FE sector, the newly introduced legislative requirement in 2007, under the FE workforce Reforms for all teachers to hold a 'licence' to practise and obtain an ITT qualification was again deregulated in August 2012. The problem that arises in this newly deregulated context, is that trainee teachers are able to enter the profession without any requirement to have qualified teacher status (QTS if in the schools' sector) or qualified teacher learning and skills (QTLS if in the post compulsory sector).

In the school sector, the accreditation for QTS is being left to the decision of head teachers based on the current 'Teachers' Standards' (DfE 2011) and the extent to which the individual has "demonstrated proficiency over a sustained period in the classroom", the current thinking is that teachers should follow a similar sustained professionalised formation to that of accountants and lawyers, sometimes 3 to 5 years. This demonstrates the continuance of a market-driven approach where schools at local level are given freedom to recruit and train teachers. Following the White Paper (DfE 2016) 'Educational Excellence Everywhere', the DfE is currently looking to strengthen QTS for teachers training to work in schools with a more challenging accreditation. The professional body for FE; the Society of Education and Training (SET), is working closely with the DfE to ensure the existing parity between QTS and QTLS remains in 
place. Similarly to the 'Teachers' Standards' (DfE 2011) for the compulsory education sector, the ETF professional standards (Education and Training Foundation 2014) comprise of 20 statements that underpin what 'professionalism' is for an FE teacher. The three subdivisions of 'professional values and attributes; professional knowledge and understanding; and professional skills,' fortify and mirror those key areas that link both education sectors and further reinforce the parity between QTS and QTLS. There is still much confusion in the sector with some PGCE PCE newly qualified teachers not being supported effectively or seeing the same parity of esteem (with schools qualified teachers) in their contracts of employment.

In 2012, Ofsted implemented a new common inspection framework for FE (DfE 2012) which identified a four-point grading scale of observing lessons across the sector; which institutions and ITT providers implemented as a measure of the 'quality and professionalism' of new and existing teachers. The more recent government announcement (GOV.UK 2016) which states that Ofsted is not going to grade lesson observations in colleges has been a welcomed shift from the box ticking exercise that is a source of stress and anxiety (O'Leary 2013). This move reinforces the current PGCE PCE philosophy at the university at the heart of this study. As in all initial teacher training (ITT) programmes, the Postgraduate Certificate in Post Compulsory Education (PGCE PCE) has an embedded teaching practice placement approach. The trainee teachers are not 'graded' in their teaching practice placement lesson observations. The focus is on the continuing professional development needs of new teachers and is fundamentally grounded in the Education and Training Foundation (ETF) Professional Standards (2014). The process is intense and philosophically grounded in promoting new teachers' merging identity as teacher from the outset. Student teachers are supported extensively through their institutional placement mentor whilst undertaking 
their teaching practice. Coupled with university mentoring on the application of pedagogical theory to teaching and learning, this support forms a fundamental part of their studies.

The current landscape of perpetual policy change, not only in FE but across all education sectors, does not look to be abating in the foreseeable future, as successive governments seek to find solutions to the ailments of social and economic policy. This reinforces Esmond and Wood's (2017) view that FE teachers' professional identity is shifting to a 'dual professionalism', where subject vocational experience and teacher as researcher need to go hand in hand. Whilst this might be the case, how does this affect those 'new entrants' into the profession? The vocational element, it appears, may well be critical if new teachers are to make the difference to the future workforce capacity to ensure national economic wellbeing. With this comes the inevitable 'accountability' for meeting targets e.g. student achievements and performance measurement against national benchmarks (DfE 2017; Ball 2010). Within the first year of teaching, all new entrants will have been observed at least once in the classroom. As stated earlier, PGCE PCE lesson observations are not graded and are situated in a strongly developmental context. That approach might contrast therefore with employer classroom observations potentially conducted through an outdated 'graded' outcome system (DfE 2016) or other institutional devised process involving possibly a teaching and learning coach or cross curricula triangulated or matrixed process.

The main focus of this research paper is to examine the transformational journeys of student teacher to qualified teacher and the notions of 'identity' within the contexts of these changing landscapes. One key part of this transformation is the development that is situated in the interaction within a group, where the social element provides learning from a community of practice that has been firmly established whilst 
on the PGCE but has still yet to be determined in their newly qualified employed positions. In this study, the researchers saw how much the political and socio-cultural context of the education sector and the context of the specific institutions in which the participants worked, influenced perspectives on the transitions they had made and their constructs of 'teacher identity'. Newly qualified teachers who have already been assessed through a rigorous ITT programme could feel that their sense of professionalism is being challenged or undermined. In an uncertain climate and within their first year post-PGCE PCE qualification, it was striking to see how the participants were variously positioned and positioning themselves as on a continuum of practice (Hall 2015).

\section{Notions of identity: from communities of practice to ecological learning systems}

To understand how it feels to 'become' a post-compulsory teacher, this research has focused on exploring that transitional phase negotiated by the emergent teacher.

Traditionally thought of as that period in which one is defined as 'newly qualified' (an NQT), to your employer and your students you are now the professional; you are now the one who is 'expert'; and you are now the one in charge - with all of the attendant expectations and responsibilities attached to such a role. Yet in this period, you are only 'just' a teacher; you have only 'just' stepped into this unknown community; and you are only 'just' beginning to work out who and what you are in relation to this emergent identity. You may have a workplace mentor and be supported with your developing professional practice; but the sense of belonging that you may have established within your pre-service studies (PGCE PCE in the context of this paper) - with your peers and your tutors - that 'safe space' within which to explore, take risks, receive constructive feedback on your academic and professional competence, has been replaced by a different community. 
So, we need to understand what may begin to influence this developing sense of identity as it shifts from an abstract to concrete concept; how, and by whom, is this validated; and what does 'membership' of this new community look and feel like?

Identity is neither static nor constructed from a single point. It is influenced by various factors, situations, contexts and relationships and as such "the development of identity is central to the careers of newcomers in communities of practice" (Lave and Wenger 1991a, 115). Constructed via a multiplicity of sources, it may be 'personal' or 'social' (Bizumic et al. 2009), but in this context, it is also 'professional'. It is situated in a cultural context (Warford 2011) within which individuals begin to develop their sense of identity as a 'teacher' (Mayes 2002) and there is an enculturation into a professional community (Brown et al. 1989; Lave and Wenger 1991b; Bruffee 1993) that is typically characterised by the three key pillars of a community of practice: mutual engagement, joint enterprise and shared repertoires (Wenger 1998).

Having a sense of belonging to any community however requires a sense of, or the possibility of, being able to participate on both a personal and social level. Influencing this is a degree of self-categorisation (Turner 1999) in relation to where and how an individual perceives they belong and as such individuals are working across two identities: the personal identity, and the 'collective' identity. In exploring this 'collective' self an individual thus identifies details about the community that enable him/her to make assumptions about whether they are even 'able' to belong (Tajfel 1972). The social identity then forms, or not, as a result of how much an individual feels 'attached' to that specific group and the ways in which others perceive that group in terms of status, norms and behaviours (Tajfel and Turner 1986).

A complex process at best, participation "suggests both action and connection; it combines doing, talking, thinking, feeling, and belonging" (Wenger 1998, 56). An 
individual may perceive that they are able to engage and so to begin that process of accommodation and assimilation of behaviours, language, and norms (Lave and Wenger 1991a), and in so doing, to develop a professional context to that sense of identity (Celuch et al. 2010). However, they may equally recognise, and feel, conflict and competition as they step into those first teaching roles and have to learn to negotiate a new environment, which includes the influence and the impact of internal and external politics.

\section{Validation}

So where does a sense of belonging come from? How is it recognised and attributed to an individual? This research was interested in exploring the point at which NQTs began to feel as though they belonged in the new workplace - and to developing an understanding of what might be contributing to, or preventing, this state of 'belonging'. Part of this process involves the development of a personal and cultural authenticity that can be ratified by the appropriate demonstration of those behaviours, norms and language as recognised by the community. Activity is only considered authentic when it is "coherent, meaningful and purposeful within a [defined] framework" (Bakhtin 1986, 9). In order for this to happen, an individual must understand the parameters and constraints of that framework, and how to negotiate it so that there is a simultaneous transformation of both social and cultural practices.

For those new to the profession and seeking to find not only their place but also their identity, "the agency of an individual builds up skills and know-how based upon successes and failures" (Bakhtin 1986, 8). Yet this creates its own tensions and conflicting perspectives in terms of how an individual rationalises what they learn and the ways in which this is "bound up with what you have to do" (Scribner 1985, 203). 
In their pre-service context, NQTs focus on developing their knowledge, skills and competence in relation to the 'teaching'. Their validation comes from their critical engagement and reflection, the discussions with their peers and their teacher educators; it is situated in their learning experiences and is regarded as that "mastery of knowledge" (Lave and Wenger 1991b, 29). This is, however, a transient community and when no longer experienced as that strong, cohesive community of practice postqualification, this sense of belonging and source of validation must be achieved and recreated elsewhere as the NQT learns to 'become' the teaching professional (Trent 2010).

\section{Membership}

We know that the process of identity development, and how that contributes to a sense of membership, does not sit in isolation - it is situated within a particular sociocultural context. The question considered by this research is how this relates to two models: a community of practice (Lave and Wenger 1999); and an ecological learning system (Hodgson and Spours 2009).

As an NQT that sense of becoming a teacher is certainly not formed at the end of one's studentship; rather this begins the 'stepping off'. An individual will have assimilated a substantial amount of declarative and procedural knowledge throughout this period, learning the 'what' and subsuming this into the 'how' teaching is enacted (Bloom and Lazerson 1988). Layered on top of this, however, is a third category of information that informs how our individual strengths and weaknesses, personal attributes, approaches to learning, and reflective capacities help us to direct that learning to expand knowledge and develop expertise in a specific field (Zimmerman 1989). This self-regulatory knowledge enables an individual to draw on the personal, environmental and behavioural aspects of social cognition (Bandura 1977, 1986) and to both influence, 
and be influenced by these in a reciprocal fashion. From a community of practice perspective, this would relate to how individuals begin to recognise the space within which established practices, processes and a sharing of knowledge are defined, with agency being generated through the collective approach (Wenger 1998, 2000). If the viewpoint is from an ecological learning systems approach, however, then those interactions are more collaborative, transactional and permeable (Hall 2015). Agency may then become much more multi-layered, engage a range of environments and contexts, and draw on a "shared framework for creative action" (Hodgson and Spours 2009, 17).

In this way it can be seen that as a newly-qualified teacher begins to make sense of their new community, the degree and direction of influence and interaction can be multi-faceted and multi-directional. In seeking to satisfy their personal needs an individual may do so "through participation in the satisfaction of collective needs" (Harris and Shelswell 2005, 173). Whilst this may be perceived as for mutual benefit, this can also result in tensions as individuals try to find ways to resolve the competing and fragmented identities of a "nexus of multi-membership" (Wenger 1998, 159).

\section{Research methodology and ethics}

This paper draws on interviews with seven volunteer participants. They were known to all three researchers in some capacity (as former and/ or current students and from three different PGCE PCE tutor groups).Two researchers conducted the interviews in March and April 2017. The third researcher analysed the interviews thematically against a continuum of practice (Hall 2015) that explored participant perceptions of their sense of identity and where this indicated their 'belonging' and 'identity'. Participants had been supplied with questions beforehand, both on consent forms and on pre-interview sheets to support their reflections: these questions are listed below. 
- What is your current context?

Are you teaching? In what capacity? (full/ part time/ agency etc.) Are you being mentored formally/ informally?

- What are your perceptions of the transition you have made post PGCE qualification?

- What is your perspective on your identification (sense of self as teacher/ construction of self as teacher) with the 'teacher' role?

- To what extent and in what ways do you feel the continuum of practice reflects your sense of your agency and development? Can you provide one or two examples to support this?

Participants were advised that every reasonable attempt would be made to ensure their anonymity and that the researchers would not directly share interview recordings (which were destroyed after having been transcribed). They understood that they could opt out and were also invited to say whether their data could be kept with a view to potential future involvement in a further phase of the research (anticipated for 20172018).

\section{Analysis and findings}

\section{Participant profiles}

- What is your current context?

Are you teaching? In what capacity? (full/part time/ agency etc.) Are you being mentored formally/ informally?

The seven participants were employed at the time of the study. The teaching contexts comprised higher education, further education (including adult and community education), and secondary school. Mentoring was characterised as informal by three of the participants. The other three described a more formal mentoring process with one 
participant describing line management rather than explicit mentoring. Formal mentoring for one participant was contact with a line manager and also referral to a learning and teaching coach.

For two participants $(1,2)$ who worked in both higher and further education, mentoring was identified as having been explicitly available through the PGCE year. Post- PGCE, mentoring was more usually experienced as peer colleague relationship and/ or as person to go to for specific information and advice in relation to working on particular course/s. It was described as 'an informal mentoring relationship that stops and starts depending on the contact you've got' (Participant 2).

For Participant 3, now full time through two contracts, mentoring had begun serendipitously and informally. Their perception of and positioning in relation to mentoring was a discussion point which will be returned to ('Reflections on continuum of practice'). Participant 4 was also full time but had moved from a college placement on the PGCE to a secondary school. Anhorn $(2008,19)$ commented: "Relationships with fellow teachers and other school staff were at the heart of the first-year teachers' sense of belonging to the staff at their school." While the participant was being formally mentored, there was some hesitancy as regards their perceived position as 'apprentice' in the community of practice (Lave and Wenger 1999) of the school. Although 'belonging' to a formally recognised professional community of practitioners, the extent to which an individual has a formally recognised 'position' within that community is less fixed, as would be their potential to influence within that community. As such, they may be more in keeping with a fluid ecological learning system at this point.

Participant 5 was on a temporary part time contract in an Adult Education setting, teaching on a range of levels and abilities. There was no formal mentoring beyond a curriculum manager's line management responsibility for workload 
allocations. This participant's experiences of mentoring and the perceptions of not belonging within a community of practice will be discussed later. Participant 6 was a permanent full time teacher in a general further education college and although they also had no formal mentoring, they acknowledged referral opportunities to a line manager as well as a teaching and learning coach (TLC) who they saw three to four times a week. This participant identified with a community of practice which they related to as 'more senior colleagues in the staffroom'. The final participant (7) was a sessional teacher for two days a week at the same institution as experienced in PGCE teaching practice. They were continuing to be mentored by the head of department (their previous PGCE mentor) and recognised the positive effect of this ongoing process.

\section{Transitions}

- What are your perceptions of the transition you have made post PGCE qualification?

This provoked very interesting discussions. Participant 1 felt more at ease in a higher education setting ('more integrated in my department') than in a further education setting in which they worked where they positioned themselves as 'student teacher' (and were there for just one day a week). Participant 2 felt they were more of a 'teaching assistant'/ 'junior member' and reflected through the interview as to how that label correlated with the type of work they were doing, potentially their perceptions of the staff team's ways of working with them (as someone explicitly training and with no higher qualification) and their own sense of self as developing teacher. For Participant 3, the transition was likened to a driving test: somebody was sat in the car but now you have passed 'you're out on your own, that's when you really start driving and that's when you really start teaching'. They characterised the PGCE experience as 'the 
imagined and what you could be and the person you want to be'. In the interview they described an empowering transition where: 'I think the biggest kind of thing for me is that I've allowed myself to feel like a teacher rather than a student'. Participant 4 felt that 'in the PGCE... I was the teacher I wanted to be'. In their employment in a school setting, they explained:

'I feel like I fall in to traps that I don't maybe want to fall in to like you know the pressure of the pressure of other things that aren't the children say or the students I always thought that the students would come first and unfortunately sometimes you feel this pressure from well you know what about what about the data..'

This led to a critique that 'these other things... that aren't revolving around the students I am not a fan of that'.

Participant 5's experiences of being temporary and part time promoted some tensions that although PGCE qualified, NQT 'rules' and expectations had somehow changed. There was a sense of being 'lost/wandering' in the first term, questioning themselves all the time but also recognising developments in their teaching (with the different range of learners, and a sense of 'surviving'). There was however no confirmation or feedback internally from their institution and: as echoed by other participants, this was something they had valued on the PGCE course. In the second term and in relation to their subject specific teaching, their confidence had returned, they were not the 'new person', they knew what they were doing and were therefore given autonomy. Similarly participant 7 being in a sessional teacher role, felt the need to 'find their feet'. Their transition post PGCE was accepted as a 'good' opportunity in the same institution that they had completed their PGCE teaching practice placement. They had taken on a new first year group that offered a 'fresh' start to 'bring out the teacher' in them, e.g. being able to set the aims for the year, whereas on the PGCE they had to take other tutors' lessons. 
For participant 6 , the transition post PGCE was particularly interesting in terms of their path to full time teaching via a number of routes. They were initially employed on a point 5 maternity leave cover whilst still completing the final month of their PGCE, so were suddenly at the 'same level as someone who had been there for 20 years'. They had a 'level of responsibility', with 'no bedding in over the summer'. They described 'need[ing] to get students through' to the end of their qualifications. That transition was referred to as 'sink or swim'. Following that contract completion and for financial reasons, they reverted back to their previous employment; though clear that they had not 'fallen out' with teaching as a career. They soon realised that they wanted to get back into teaching and secured a visiting lecturer post whilst still continuing in their employment at weekends. Interestingly, this aspect gave them kudos in relation to classroom teaching as they were up to date in their vocational context (Esmond and Wood 2017). The post then became permanent full-time lecturer.

\section{Identification with teacher role}

- What is your perspective on your identification (sense of self as teacher/ construction of self as teacher) with the 'teacher' role?

Participant 1 'felt very strongly that my transition from student teacher to teacher came half way through my PGCE'. They were feeling more comfortable in one setting in a department where 'they encouraged me to act as teacher'. In relation to achieving the PGCE, they confirmed: 'when I was qualified it did kind of give me a bit of a confidence boost ....now I can be a professional'. Teacher characteristics included proactive attention to student voice, resource development, and clear sense of teaching and learning as own 'area of expertise'. In contrast, there was a sense of 'disconnect' expressed in relation to their other setting experience. For participant 2, the identification of self as teacher (shared by 1) was very much grounded in recognition of 
own personal context, experience and perceptions i.e. 'like last semester I was given a lot of teaching and I did feel more accomplished and did identify as a teacher'. As 'teacher', they characterised themselves as 'warm', 'very inclusive', 'strength is support'. Both participants $(1,2)$ referred to the influence of praise on their sense of self as teacher, e.g. (1) 'everything I do they praise quite a lot and they ask for my opinion on things and I'm very much treated as if I'm valued there', (2)

'I kind of felt post PGCE I miss that I miss the buzz of the observations I miss having an established teacher say you've done well you did this right because I don't feel I am doing that right and it's like well where do you get that praise from'.

Validation for participant 3 came from their interview for their teacher contract. Though teaching there prior to the interview, "nobody saw me nobody knew what I was doing and I was really lacking confidence and everything I was doing I was thinking this can't be right surely'. They outlined ongoing transitions in their development: 'I'm kind of still defining and finding my perfect teacher self I'm actually kind of discovering how to be an adult and be responsible at the same time'. Actually they identified themselves as 'adult' in the classroom. Recognising emotional needs and previous (possibly traumatic) histories of students, they referred to 'positioning [as] very important to me':

'I think about it every day about how I can amend myself and change my footing to help them to know that it's a fun kind of happy positive space but that also I'm looking after them I care about them and I have to be stern with them so it's a real kind of gentle balance that I have to try and create and sometimes it's not perfect of course it's not but it's very much on my mind all of the time about which kind of branch of my teacher identity I need to really use that day to get the best of them or to make them feel kind of safe..' 
Participant 4's transition from college (previous PGCE placement) to school setting (current place of work) was influential both in terms of their teacher identity where 'I identify myself as like a [parent] now' and their subject specific teacher identity where 'because I'm teaching ..[course level] as well now and that's very different I feel like I'm less lenient'. That sense of subject identity was powerfully expressed by participant 5 who discussed two identities: 'mainstream teacher' (own subject area) and 'life skills' teacher (with a different student group); described as 'completely different, everything is at a different speed, I don't assess them in the same way, I feel less like a teacher doing it'. That conflict continued in terms of being 'validated' as a teacher by a department head; on the one hand praised for displaying student work; 'you're a breath of fresh air in this department', to being undermined in their 'quality' observation feedback by another line manager. The feedback received was not reflective of the 'good' graded observation outcome and had left the participant feeling 'dispensable', 'don't feel part of the organisation..... don't feel I fit in'.

Their reflections reinforced the importance of an affirmative learning environment for transitioning teachers. They had a 'PGCE identity', but went into an organisation where it's completely different. Their perception is that they 'don't fit into the community of practice', they now have reoccurrences of 'imposter syndrome' (Brookfield 1995). Their perceptions of not belonging within a community of practice included a dismantling of their hard earnt PGCE teacher identity. In a drive to maintain and exercise their own sense of agency, they have sought a community of practice outside the workplace through their continuing professional development (CPD) on a Masters programme, creating an opportunity to share experiences with other peers and NQT's (Lave and Wenger 1999). 
The 'headline' for participant 6 was quite clearly 'I am a teacher, this is my career and I am a professional', but still getting 'first experiences' and realising this could well be the case in 20 years' time. For participant 7 , the sense of being a teacher has come from being 'set things to do', having responsibility for student assessments. They recognised: 'I've been thrown in the deep end a little bit, but you learn from that'. All three participants $(5,6,7)$ needed confirmation about how their work was developing through seeking 'counsel' with their line manager. Having identified some doubts, participant 6 felt 'confident now to find out and put things right'. 'Validation' was a common theme with the onset of an internal 'quality' observation on the horizon and an opportunity for seeking advice dealing with student groups that are a combination of different levels.

\section{Reflections on the continuum of practice}

- To what extent and in what ways do you feel the continuum of practice reflects your sense of your agency and development? Can you provide one or two examples to support this?

The continuum of practice (Hall 2015) was a theoretical lens through which to explore participant perceptions of their sense of identity and where this indicated their 'belonging' and 'identity'. Transitions oscillated between a more traditional masterapprentice model to an increasingly independent and multi-layered approach initiated through ecological learning systems.

It was striking to see how participant 1 was distancing themselves from their original 'community' with a clear recognition that they have 'a valuable contribution to make that is unique to me'. They were also exemplifying a mentoring approach that was explicitly peer to peer; described as actively positioning themselves as 'co-learner'. A shifting theoretical perspective between community of practice and ecological learning 
systems was particularly apparent in their reflection that 'my perception of myself is really influenced by other people and the way that they see me and the way that they treat me'. For Participant 2, professional relationships were not harmonious but also not particularly conflicting. As noted earlier, they perceived and problematised their identification of themselves as variously more like a 'teaching assistant' without the 'validation' (and associated power) of a higher qualification and/ or accumulated experience. Looking through the lens of ecological learning systems, this participant's identity was being shaped by their interactions with others and the varied responsibilities they were allocated (teaching or support): 'last semester I was given a lot of teaching and I did feel more accomplished and did identify as a teacher..'

Participant 3 identified a shift to a more agentic approach while on the PGCE course in tune with ecological learning, i.e. 'I had to hunt the [colleagues] out I had to find them out'. Interestingly, in gaining a contract, they had shifted back to a 'master apprentice kind of situation with my informal mentor' which was described in a more ambivalent way. It was noticeably 'for a very very short time I had that master apprentice kind of experience' (related to a period on the PGCE). They felt that they had only been 'accepted' as member of the community having been taken on permanently having previously 'had to elbow my way in'. Reflections included a recognition now of being 'very respectful' (i.e. of 'my managers and my colleagues'), but also empowered to 'start kicking back' if needed so as not to 'put myself in a position where I don't feel comfortable with my teaching or my teaching ethics'. This illustrated a desire for a devolution and absence of 'power' within the relationship. The participant therefore oscillated between community of practice and ecological learning systems as they expressed recognition of the value placed on position and knowledge, but also a heightened sense of their own agency. 
Participant 4 also described tensions. Their school colleagues acknowledged them recognising them as a 'newly qualified teacher', however; while that interaction was 'respect[ed]' (and tied in part to the age difference between the participant and their older, more experienced colleagues), there was a caveat that 'I would have liked that role to have shifted to maybe peer peer but maybe that will change over time'. For participant 5 , relations were explicitly problematic:

'They are trying to change me in ways I am against, they're trying to change me personally and as a person and I'm dead set against that and because they're not working with me I'm finding myself not wanting to work with them which is making feel worse'.

They recognised the need to hold on to their sense of self as agentic and independent: 'I'm pushing against that because I don't want to change ... it back, because it took me far too long to get my identity to where it was'. In part, that sense of identity was connected to the fact that: 'I'm the only one with a PGCE there I do not fit in with their community'. For them, a community of practice should feel harmonious and should see colleagues working together in a shared enterprise. However the relationships and influences in their community at work were experienced as transitory and conflicting: 'They are trying to change me in ways I am against', 'I'm being asked to change my identity really in order to fit into the organisation'.

This contrasted strongly to the experience of participant 6 for whom their subject experience had seen increased validation. Informed by the status acquired from currency in their vocational area, this participant described significant transitions from 'apprentice' to 'master' (Lave and Wenger 1999). Reflecting on a previous point 5 maternity leave cover (indicated earlier), they described themselves as an 'imposter' (Brookfield 1995). In contrast, in their full time permanent post, they found that they 
were an 'important part of a team'. They shared an increased confidence in their role and their sense of being valued as 'one off the production line', having more up to date skills. This confirmation of teacher identity surprised them; they were now being asked 'how to' or could colleagues sit in on their lessons. Through the influence of the community at work, their position was validated and shaped (from 'apprentice' to 'master'). Participant 7 seemed to be similarly at ease within a community of practice in their organisation (previous PGCE placement) explaining:

'I don't feel just like a trainee teacher anymore, where I'm called in to do certain things and go home, I feel more involved, when we have dept [department] meetings, I can put my thoughts across'.

\section{Conclusion}

The research explored oscillating and at times conflicting/ unclear shifts along a continuum of practice from community of practice to ecological learning systems. Common themes emerged through the data around identity, validation and membership. These concepts were linked, for instance explicit praise and/ or acknowledgement of the participant as a member of their workplace community seemed to inform a more confident sense of self as working within that community of practice. Perceptions of membership were also strengthened or weakened through personal identification with the varied categories of employment contracts. All participants shared aspirations for continuing to develop their teaching practice. Those aspirations included: wanting to have a say, wanting to try new things, wanting to take (increased) ownership, wanting to support students (welfare and academic development), wanting to learn and develop themselves.

There was a sense that the participants are all; in their own identification of themselves as new teachers, their recent completion of the PGCE, and their colleagues' identification of them as new teachers, positioning themselves primarily as 
'apprentices'. An apprentice in that context is a lifelong learner and aspirations to evolve and to make changes (whether individually and/ or in relation to institution or educational practices) were clearly communicated through the data. The research illustrates the extent to which, and some of the ways in which, communities of practice, however strongly or weakly they are established, play a powerful role in shaping, informing and influencing an individual's sense of membership and identity. What is also strongly apparent through the data set is that very natural human desire to be 'validated', to be told we are doing the right thing, we are doing well. Such validation could also stem (as is explicit in some of the participants' reflections) from less hierarchical models of mentoring (both informal and formal) and more explicit sharing of teaching practices and positive ongoing recognition such as is key for NQTs/ transitioning student teachers.

\section{Recommendations}

The study advocates professional learning cultures that may better nurture and promote teachers' sense of identity and agency, supporting a range of collaborative learning opportunities including access to informal and formal mentoring structures. This is particularly important for NQTs/ transitioning student teachers within the context of the market-driven, consumer and employer-led policy discourse described earlier in this paper. A key implication of this research is therefore that all teachers - new and experienced alike - are facilitated to develop communities of practice as a secure foundation from which an increased sense of own agency can be commanded. The development of such communities could safeguard the inclusion and the development of their members. In recognising all members (experienced and new in post) as lifelong learners, communities of practice could provide access to wider opportunities as well as enabling the secure and confident ongoing development of teaching skills. This is 
reflected in the Carter Review $(2015,20)$ where one of the answers to the issue of trainees needing to secure subject knowledge as well as developing effective pedagogical research is achieved by "the establishment of stronger subject communities, with trainees having access to subject experts".

In this study, all of the participants had obtained the PGCE PCE qualification. Importantly, all participants reflected on a need to belong and to be seen to belong; something they recognised in relation to the PGCE course but that was variously more or less apparent in their workplace settings. What also came through strongly was that desire to belong as the teacher they themselves wanted to be; in recognition of their own strengths and areas of development, positioning themselves as lifelong learners, and expressing their sense of moral responsibility in the role. It is therefore suggested that the natural desires to belong and to be acknowledged should inform the development of workplace communities as supportive and evolving spaces for reflection and action. The relations in those communities should be experienced as less hierarchical, placing explicit emphasis on the sharing of teaching and learning approaches and supporting critically informed discussions of the context in which as teachers, we all find ourselves (individually, within our institutions, within the educational context and wider policy arena). Those communities might include informal mentoring processes such that proactively work to strengthen and develop a member's sense of confidence in their work, encouraging new approaches and enabling individual voices to engage critically in the discourse of education (policy and practice). 


\section{References}

Anhorn, R. 2008. "The profession that eats its young.” The Delta Kappa Gamma Bulletin 74 (3): 15-22.

Bakhtin, M. 1986. Speech genres and other late essays. Austin, TX: University of Texas Press.

Ball, S. 2010. "The Teacher's soul and the terrors of performativity." Journal of Education Policy 18 (2): 215-228. doi: 10.1080/0268093022000043065. http://www.researchgate.net/profile/Stephen_Ball6/publication/232916965.pdf Bandura, A. 1977. Social learning theory. Englewood Cliffs, NJ: Prentice-Hall. Bandura, A. 1986. Social foundations of thought and action: A social cognitive theory. Englewood Cliffs, NJ: Prentice-Hall.

Bizumic, B., K. 1. Reynolds, J. C. Turner, D. Bromhead, and E. Subasic. 2009. "The role of the group in individual functioning: school identification and the psychological well-being of staff and students." Applied Psychology: An International Review 58 (1): $171-192$.

doi: 10.1111/j.1464-0597.2008.00387.x.

Bloom, F.E., and A. Lazerson. 1988. Brain, mind, and behaviour. New York: Freeman. Brookfield, S. 1995. Becoming a Critically Reflective Teacher. University of Michigan: Wiley.

Bruffee, K. 1993. Collaborative learning: higher education, interdependence, and the authority of knowledge. Baltimore, MD: John Hopkins University Press.

Brown, J. S., A. Collings, and P. Duguid. 1989. "Situated cognition and the culture of learning." Educational Researcher 18(1): 32 - 42.

doi: 10.3102/0013189X018001032. 
Carter, Sir Andrew. 2015. Carter Review of Initial Teacher Training (ITT). Department for Education.

https://www.gov.uk/government/uploads/system/uploads/attachment_data/file/399957/ Carter_Review.pdf.

Celuch, K., I. Kozlenkova, and G. Black. 2010. "An exploration of self-efficacy as a mediator of skill beliefs and student self-identity as a critical thinker." Marketing Education Review 20 (3): 25-264.

DBIS, and DfE. 2015. Post-16 Education and Training Institutions Review. London: Department for Business, Innovation and Skills and Department for Education. https://www.gov.uk/government/publications/post-16-education-and-training$\underline{\text { institutions-review }}$

DfE. 2010. The Importance of Teaching: The Schools White Paper 2010. https://www.gov.uk/government/publications/the-importance-of-teaching-the-schoolswhite-paper-2010

DfE. 2011. Teachers' Standards. https://www.gov.uk/government/publications/teachers-standards DfE. 2012. Ofsted Common Inspection Framework for Further-Education-and-Skills from September 2012.

https://www.gov.uk/government/publications/common-inspection-framework-forfurther-education-and-skills-2012

DfE. 2016. Educational Excellence Everywhere.

https://www.gov.uk/government/publications/educational-excellence-everywhere DfE. 2017. Ofsted Further Education and Skills Inspection Handbook from April 2017. https://www.gov.uk/government/publications/further-education-and-skills-inspection$\underline{\text { handbook }}$ 
Education and Training Foundation. 2014. Professional Standards for FE teachers. Accessed 4 September 2017.

http://www.et-foundation.co.uk/supporting/support-practitioners/professional-standards/ Esmond, B., and H. Wood. 2017. "More morphostasis than morphogenesis? The 'dual professionalism' of English Further Education workshop tutors." Journal of Vocational Education and Training 69 (2): 229-245.

doi: 10. 1080/13636820.2017.1309568.

Gleeson, D., J. Hughes, M. O’Leary, and R. Smith. 2015. “The state of professional practice and policy in the English further education system: a view from below." Research in Post-Compulsory Education 20 (1): 78-95.

doi: 10.1080/13596748.2015.993877.

GOV.UK (2016) Guidance. Ofsted inspection: myths.

https://www.gov.uk/government/publications/school-inspection-handbook-fromseptember-2015/ofsted-inspections-mythbusting

Hall, V.J. 2015. "Teacher-student interactions: communities of practice, ecological learning systems- or something else?" Journal of Further and Higher Education 41 (2): 120-132. doi: 10.1080/0309877X.2015.1070395.

Harris, S., R., and N. Shelswell. 2005. "Moving Beyond Communities of Practice.” In Beyond Communities of Practice: Language, Power and Social Context, edited by Barton, D., and K. Tusting, 158 - 179. New York: Cambridge University Press. Hodgson, A., and K. Spours. 2009. Institution for Lifelong Learning: Collaborative Local Learning Ecologies: Reflections on the Governance of Lifelong Learning in England. IFLL Sector Paper 6. Leicester: NIACE.

Lave, J., and E. Wenger. 1991a. "Legitimate peripheral participation in communities of practice." In Supporting lifelong learning Vol 1: Perspectives on learning, edited by 
Harrison, R., F. Reeve, A. Hanson, and J. Clarke, 111 - 126. London: Routledge Falmer.

Lave, J., and E. Wenger. 1991b. Situated learning: Legitimate peripheral participation. Cambridge: Cambridge University Press.

Lave, J., and E. Wenger. 1999. "Learning and Pedagogy in Communities of Practice." In Learners and Pedagogy, edited by Leach, S., and B. Moon, 21-34. London: Paul Chapman Publishing Ltd.

Leitch, A. 2006. Review of Skills - Prosperity for all in the Global Economy - World Class Skills (Final Report). Norwich: HMSO.

Mayes, T. 2002. "The technology of learning in a social world." In Supporting lifelong learning, Vol. 1, edited by Harrison, R., F. Reeve, A. Hanson, and J. Clarke, 163-175. London: Routledge Falmer.

Mutton, T., K. Burn, and I. Menter. 2016. "Deconstructing the Carter Review: competing conceptions of quality in England's 'school-led' system of initial teacher education."Journal of Education Policy 32 (1): 14-33.

doi: 10. 1080/02680939.2016.1214751.

O’Leary, M. 2013. Developing a National Framework for the Effective Use of Lesson Observation in Further Education:Project Report for UCU. UCU. http://www.ucu.org.uk/media/pdf/i/q/ucu_lessonobsproject_nov13.pdf Scribner, S. 1985. “Knowledge at work.” Anthropology and Education Quarterly 16 (3):199- 206 .

Smith, R., and M. O’Leary. 2013. "New Public Management in an age of austerity: knowledge and experience in further education." Journal of Educational Administration and History 45 (3): 244-266. doi: 10.1080/00220620.2013.796913. 
Tajfel, H. 1972. “La catégorisation sociale.” In Introduction à la Psychologie

Sociale Vol. I, edited by Moscovici, S., 272-302. Paris: Larousse.

Tajfel, H., and J.C. Turner. 1986. "The social identity theory of intergroup behaviour." In Psychology of intergroup relations, edited by Worchel, S. and W. G. Austin, 724. Chicago: Nelson Hall.

Trent, J. 2010. "Teacher education as identity construction: insights from action research." Journal of Education for Teaching 36 (2): 153 - 168.

Turner, J. C. 1999. "Some Current Issues in Research on Social Identity and Selfcategorisation Theories." In Social Identity: context, commitment, content edited by Ellemers, N., R. Spears and B. Doojse, 6 - 34. Oxford: Blackwell.

Warford, M. K. 2011. "The zone of proximal teacher development.” Teaching and Teacher Education 27 (2): 252 - 258. doi: 10.1016/j.tate.2010.08.008.

Wenger, E. 1998. Communities of Practice. Learning, Meaning and Identity. New York: Cambridge University Press.

Wenger, E. 2000. "Communities of practice and social learning systems.” In Supporting lifelong learning, Vol. 2: Organising learning, edited by Reeve, F., M. Cartwright and R. Edwards. 2002. 160 - 179. London: Routledge Falmer. Wright, V., T. Loughlin, and V. Hall. 2017. "Lesson observation and feedback in relation to the developing identity of student teachers." TEAN Journal 9 (1):100-112. Zimmerman, B. J. 1989. "A social cognitive view of self-regulated academic learning." Journal of Educational Psychology 81(3): 329-339. 